\title{
Pengembangan Bahan Ajar Menulis Deskripsi Menggunakan Model Circuit Learning pada Siswa Kelas VII SMP di Samarinda
}

\author{
Development of Writing Description Teaching Materials Using Circuit Learning Model \\ for Class VII Students in Samarinda
}

\author{
${\text { Rakhmad Syarif }{ }^{1}{ }^{*}, \text { M. Bahri Arifin }}^{2}$, dan Mohammad Sidik ${ }^{3}$ \\ ${ }^{1}$ Magister Pendidikan Bahasa dan Sastra, FKIP, Universitas Mulawarman \\ ${ }^{2}$ FIB Universitas Mulawarman \\ ${ }^{3}$ FKIP Universitas Mulawarman \\ 1,* Corresponding email: syarifrakhmad17@gmail.com \\ ${ }^{2}$ Email: mbahriarifin12@gmail.com \\ ${ }^{3}$ Email: hmsiddik@yahoo.com
}

Received: 2 June 2020 Accepted: 9 January 2021 Published: 1 June 2021

\begin{abstract}
Research on the development of teaching materials for writing descriptions using the learning model of Circuit learning needs to be done because teachers and students have difficulty learning the process of writing descriptions. This study aims (1) to find out the process of developing teaching materials in writing descriptions by using the Circuit Learning model (2) to measure the quality of teaching materials writing descriptions using circuit learning methods assessed from the validity and effectiveness. This study applies research and development methods conducted at Nabil Husen junior high school Samarinda. The results of development research can be seen from the validation results, namely material validation with a value of 88 , graphic validation with a value of 86 and a validation of language values with a value of 97 with very valid criteria. The effectiveness test results seen from the implementation of the lesson plan, the teacher's response value 93, the students' response value 93 and the value of the description writing test results obtained an average value of 88 with very effective criteria. Thus, the research development of teaching material writing descriptions by using the learning model of circuit learning in class VII students is very valid and effective.
\end{abstract}

Keywords: teaching materials, writing descriptions, circuit learning model

\begin{abstract}
Abstrak: Penelitian pengembangan bahan ajar menulis deskripsi dengan menggunakan model pembelajaran circuit learning perlu dilakukan karna guru dan siswa mengalami kesulitan dalam proses pembelajaran menulis deskripsi. Penelitian ini bertujuan (1) untuk mengetahui proses pengembangan bahan ajar menulis deskripsi dengan menggunakan model pembelajaran circuit learning (2) untuk mengukur kualitas bahan ajar menulis deskripsi dengan menggunakan metode circuit learning yang dinilai dari kevalidan dan keefektivitasan. Penelitian ini menerapkan metode penelitian dan pengembangan yang dilaksanakan di SMP Nabil Husen Samarinda. Hasil penelitian pengembangan dapat dilihat dari hasil validasi, yakni validasi materi dengan nilai 88 , validasi grafika dengan nilai 86 dan validasi nilai bahasa dengan nilai 97 dengan kriteria sangat valid. Hasil uji keefektivitasan dilihat dari keterlaksanaan RPP, nilai respons guru 93, nilai respons siswa 93 dan nilai hasil tes menulis deskripsi yang dilakukan mendapat nilai rata-rata 88 dengan kriteria sangat efektif. Dengan demikian dapat disimpulkan bahwa penelitian pengembangan bahan ajar menulis deskripsi dengan menggunakan model pembelajaran circuit learning pada siswa kelas VII ini sangat valid dan sangat efektif.
\end{abstract}

Kata kunci: bahan ajar, menulis deskripsi, model circuit learning

To cite this article:

Syarif, R., Arifin, M. B., \& Sidik, M. (2021). Pengembangan Bahan Ajar Menulis Deskripsi Menggunakan Model Circuit Learning pada Siswa Kelas VII SMP di Samarinda. Diglosia: Jurnal Kajian Bahasa, Sastra, dan Pengajarannya, 4(2), 219-226. https://doi.org/10.30872/diglosia.v4i2.70 


\section{A. PENDAHULUAN}

Pendidikan di era sekarang ini merupakan permasalahan yang sangat menarik didiskusikan pada banyak forum, dari forum formal maupun nonformal; mulai dari kebijakan, sistem, sampai sumber daya tenaga pendidiknya. Setiap diskusi tersebut banyak memunculkan inovasi-inovasi dan ide-ide yang sangat baik untuk kemajuan dunia pendidikan sebagaimana dicita-citakan dalam visi pendidikan nasional, yaitu mewujudkan sistem pendidikan sebagai pranata sosial yang kuat dan berwibawa untuk memberdayakan semua warga Indonesia agar berkembang menjadi manusia yang berkualitas sehingga mampu dan proaktif menjawab tantangan zaman yang selalu berubah. Untuk mewujudkan visi tersebut, seluruh sumber daya pendidik harus mengeluarkan segala daya dan upaya agar mampu menghasilkan pendidikan yang berkualitas bagi peserta didik. Oleh karena itu, perubahan yang berkelanjutan evaluasi dan kemudian revisi kurikulum pendidikan selalu dilakukan guna memenuhi tuntutan dan tujuan pembelajaran yang berorientasi dari sebuah proses pendidikan.

Rahmawati (2018) mengemukakan bahwa kemajuan ilmu pengetahuan saat ini, memerlukan kurikulum yang lebih kompleks untuk mencapai keterampilan anak yang bisa bersaing dalam kehidupan modern. Selain itu, Salahudin (2010) juga mengungkapkan bahwa kurikulum merupakan instrumen pendidikan yang wajib dimiliki oleh satuan pendidikan dalam menyajikan mata pelajaran kepada peserta didik dengan teori yang benar memiliki dasar moralitas dan falsafah.

Pengembangan kurikulum sampai pada diberlakukannya Kurikulum 2013 diharapkan mampu menjawab tantangan zaman sampai tuntutan yang harus dipenuhi dan mampu mengoptimalkan teknologi yang sudah berkembang dalam proses pembelajaran. Generasi muda saat ini merupakan penggerak tongkat estafet kemajuan suatu bangsa. Generasi muda harus mampu menunjukkan karakter yang sesuai dengan nilai-nilai Pancasila.

Bahan ajar merupakan seperangkat sarana atau alat pembelajaran yang berisi materi pembelajaran, metode-metode, batasan dan cara mengevaluasi yang didesain secara sistematis dan menarik dalam rangka mencapai tujuan pembelajaran yang diharapkan. Bahan ajar sangat berpengaruh terhadap materi yang disampaikan guru kepada peserta didik, sehingga bahan ajar sangat diperlukan untuk mampu mewadahinya. Bahan ajar mempengaruhi keberhasilan peserta didik dalam proses belajar selain peranan seorang guru, maka dari itu perlu dirumuskan bahan ajar yang mampu mendukung terselenggaranya pendidikan yang baik, khususnya dalam hal ini adalah mata pelajaran bahasa Indonesia. Idealnya materi pembelajaran harus relevan dengan kompetensi yang dibutuhkan, materi esensial harus sesuai dengan tingkat perkembangan anak. berkaitan dengan pembelajaran bahasa dan sastra Indonesia. Saat ini banyak bahan ajar yang dapat guru pilih, namun bahan ajar yang sesuai dengan kebutuhan guru dan peserta didik masih sulit ditemukan. Pada umumnya bahan ajar yang tersedia tersebut untuk kompetensi dasar secara keseluruhan baik untuk aspek keterampilan menyimak, berbicara, membaca dan menulis.

Menulis merupakan salah satu kemampuan yang perlu dimiliki oleh siswa mulai sekolah dasar sampai sekolah lanjutan. Dengan memiliki kemampuan menulis kreatif dan kritis siswa dapat berkembang. Selain itu, keterampilan ini akan menunjang kelanjutan studi mereka ke lembaga pendidikan yang lebih tinggi maupun bekal untuk bekerja. 
Pada umumnya, siswa kurang berminat pada kegiatan menulis. Mereka lebih menyukai berkomunikasi secara lisan karena berkomunikasi secara lisan lebih mudah dibandingkan berkomunikasi secara tertulis. Hal inilah yang menyebabkan siswa tidak mampu melakukan kegiatan menulis sebagai perwujudan bentuk komunikasi tertulis. Masalah pengajaran bahasa Indonesia terutama keterampilan menulis perlu mendapat perhatian dan penekanan yang intensif dari guru bahasa Indonesia karena keterampilan menulis merupakan salah satu subpokok bahasan dalam pengajaran bahasa Indonesia di Sekolah Menengah Pertama. Oleh karena itu, pembelajaran keterampilan menulis harus dikuasai setiap siswa.

Proses belajar mengajar merupakan interaksi antara guru dan siswa serta lingkungan sekitarnya. Interaksi dalam pembelajaran sangat diperlukan untuk menjalin kerja sama antara guru dan siswa saling mendapatkan umpan balik yang berguna untuk menambah ilmu (Hudiyono, Rokhmansyah, \& Elyana, 2021). Hamalik (2009) menjelaskan pembelajaran merupakan suatu sistem yang saling berintegrasi satu sama lainya membentuk prosedur untuk capaian sebuah indikator pembelajaran. Tujuan pembelajaran merupakan tercapainya suatu perilaku atau kompetensi pada siswa setelah mengikuti rangkaian pembelajaran. Proses pembelajaran harus diawali dengan komunikasi yang baik antara guru dan peserta didik, sehingga kegiatan pembelajaran mampu tersusun dengan sistematika yang sesuai dari rencana pelaksanaan pembelajaran, pelaksanaan pembelajaran, serta evaluasi pembelajaran yang mengacu kepada kurikulum yang berlaku disekolah, Kurikulum yang berlaku saat ini adalah Kurikulum 2013.

Berkaitan dengan berbagai macam materi yang ada di dalam kurikulum 2013 untuk kelas VII ada beberapa jenis teks yang dimuat dalam pembelajaran bahasa Indonesia, terdiri dari teks eksposisi, narasi, argumentasi dan deskripsi. Dalam penelitian ini Peneliti fokus pada teks deskripsi. Fenomena di kelas berdasarkan observasi awal penulis menunjukkan bahwa pembelajaran menulis karangan deskripsi di kelas VII SMP Nabil Husen dilaksanakan dengan berorientasi pada hasil dan mengabaikan proses. Proses menulis ini menyebabkan siswa kurang kreatif dalam menciptakan ide, lambat dalam proses menulis, siswa sulit menggambarkan suatu objek, dan sebagainya. Sistem pembelajaran menulis tersebut merupakan pandangan lama sehingga karangan siswa yang dinilai itu banyak mengalami kesalahan. Hal inilah memengaruhi pembelajaran menulis penting diterapkan dengan menggunakan pendekatan keterampilan proses.

Tujuan Kurikulum 2013, yaitu siswa diharapkan mampu mengungkapkan informasi dalam bentuk karangan deskriptif. Untuk mencapai hal-hal tersebut diperlukan pendekatan pembelajaran menulis yang lebih kreatif dan inovatif dalam mengolah bahan ajar, yaitu dengan pendekatan Model pembelajaran Circuit learning. Pendekatan model pembelajaran circuit learning dalam pembelajaran menulis menuntun siswa agar mampu melakukan proses menulis, mulai dari penciptaan ide, pemaparan isi tulisan, pengorganisasian tulisan, pemakaian kalimat secara efektif, dapat menggunakan pilihan kata yang tepat, pemakaian ejaan dan tanda baca, serta dapat membuat paragraf yang baik. Selain itu, siswa dapat mengomunikasikan ideide atau gagasan-gagasan, argumen-argumen serta mampu memberi bentuk kepada segala sesuatu yang ia rasakan, berupa rangkaian kata secara tertulis, tersusun dengan sebaik-baiknya sehingga gagasannya itu dapat dipahami dan dapat dipetik manfaatnya dengan mudah oleh orang lain. 
Pembelajaran menulis dengan model pembelajaran circuit learning menuntut guru harus memahami aspek-aspek menulis, memiliki kemampuan menulis yang mandiri dan pendekatan ini membimbing siswa secara terarah. Di samping itu, pendekatan ini memberikan motivasi kepada siswa untuk mengamati lingkungannya. Dengan pengamatan tersebut tentunya siswa akan termotivasi untuk menulis deskriptif berdasarkan objek yang telah diamati di bawah bimbingan guru tersebut. Menulis deskripsi memberi kesempatan kepada peserta didik untuk bekerja dengan ilmu pengetahuan, tidak sekadar mendengar cerita atau penjelasan guru mengenai suatu ilmu pengetahuan. Justru di sisi lain mereka bisa merasa berbahagia dengan peran aktifnya sebagai ilmuwan.

Pendidik diharapkan mampu mengembangkan bahan ajar karena materi yang ada di dalam buku pegangan peserta didik dan pendidik setiap tahun mengalami perubahan dalam waktu yang lama. Dengan melakukan pengembangan bahan ajar, pendidik dapat menyusun bahan ajar sesuai kebutuhan mata pelajaran khususnya pada mata pelajaran bahasa Indonesia tentunya pendidik harus di tuntut selalu berinovasi dalam proses pembuatan bahan ajar agar tujuan pembelajaran terlaksana dengan baik.

SMP Nabil Husen Samarinda adalah salah satu satuan pendidikan yang menerapkan kurikulum 2013. Keberadaan kurikulum ini menyebabkan satuan pendidikan ini harus menerapkan pembelajaran dengan menitikberatkan pendidikan karakter dalam KI-1 dan KI-2. Satuan pendidikan yang bernaung di bawah dinas pendidikan kota Samarinda ini harus selalu mampu berinovasi agar tercapai pembelajaran yang berkualitas.

Berdasarkan uraian di atas, maka penelitian ini bertujuan (1) untuk mengetahui proses pengembangan bahan ajar menulis deskripsi dengan menggunakan model pembelajaran circuit learning (2) untuk mengukur kualitas bahan ajar menulis deskripsi dengan menggunakan metode circuit learning yang dinilai dari kevalidan dan keefektivitasan.

\section{B. METODE}

Metode penelitian yang digunakan adalah metode penelitian dan pengembangan $(R \& D)$. Penelitian dan pengembangan $(R \& D)$ adalah proses yang digunakan untuk mengembangkan dan memvalidasi produk pendidikan (Subaidah, Susilo, \& Siddik, 2020). Hasil dari pengembangan bahan menulis deskripsi dengan model pembelajaran circuit learning pada siswa kelas VII SMP Nabil Husein Samarinda ini diharapkan dapat membantu siswa dalam meningkatkan minat belajar siswa sehingga akan berpengaruh pada peningkatan hasil belajar siswa. Tingkat kelayakan bahan ajar menulis deskripsi dengan menggunakan model circuit learning ini divalidasi oleh ahli materi, ahli Bahasa, guru pengampu dan diuji coba penggunaannya oleh siswa.

Gall et al. (2003) memaparkan sepuluh langkah pelaksaan strategi penelitian dan pengembangan sebagai berikut. Pertama, penelitan dan pengumpulan data (Research and Information Collecting) yang meliputi pengukuran kebutuhan, studi literatur, penelitian dalam sekala kecil dan pertimbangan-pertimbangan dari segi nilai. Kedua, perencanaan (planning), yaitu menyusun rencana penelitian meliputi kemampuankemampuan yang diperlukan dalam pelaksanaan penelitian, rumusan tujuan yang hendak dicapai dengan penelitian tersebut, desain atau langkah-langkah penelitian, dan memungkinkan dalam lingkup terbatas. Ketiga, pengembangan draf produk 
(develop preliminary form of product). Pengembangan bahan pembelajaran, proses pembelajaran dan instrumen evaluasi. Keempat, uji coba lapangan awal (preliminary field testing). Uji coba di lapangan pada satu sampai tiga sekolah dengan enam sampai dua belas subjek uji coba (guru). Selama uji coba dilakukan pengamatan, wawancara dan pengedaran angket. Kelima, merevisi hasil uji coba (main productrevision). Keenam, uji coba lapangan (main filed testing) melakukan uji coba yang lebih luas pada 5 sampai dengan 15 sekolah dengan 30 sampai 100 orang subjek uji coba. Data kuantitatif penampilan guru sebelumnya dan sesudah menggunakan model yang dicobakan dikumpulkan. Ketujuh, penyempurnaan Produk hasil uji lapangan (oprasional productrevision). Kedelapan, penyempurnaan produk hasil uji lapangan (oprasional field testing). dilaksanakan pada 10 sampai 30 sekolah melibatkan 40 sampai dengan 200 subjek. Pengujian dilakukan melalui angket, wawancara, observasi dan analisis hasilnya. Kesembilan, penyempurnaan produk akhir (final productrevision). Kesepuluh, disemanisasi dan implementasi (dissemination and implemation).

Prosedur penelitian yang dilakukan peneliti dalam pengembangan ini diadaptasi dari langkah-langkah pengembangan yang dikembangkan oleh Gall et al. (2003) tersebut dengan pembatasan. Yundayani et al. (2017) menyatakan bahwa dimungkinkan untuk membatasi penelitian dalam sekala kecil, termasuk membatasi langkah penelitian penerapan langkah-langkah pengembangan disesuaikan dengan kebutuhan peneliti.

\section{PEMBAHASAN}

Data yang dianalisis pada penelitian terdiri atas angket validasi ahli dan data uji coba. Validasi dilakukan tiga orang validator yaitu ahli bahasa, ahli materi, dan ahli grafika yang bertujuan untuk memvalidasi tingkat kevalidan bahan ajar (Rajja, Arifin, \& Mursalim, 2020). Menulis deskripsi dengan model pembelajaran circuit learning pada siswa kelas VII SMP Samarinda. Uji coba dilakukan oleh guru dan siswa kelas VII SMP Nabil Husen Samarinda yang bertujuan mengetahui tingkat kemenarikan bahan ajar yang digunakan dalam proses pembelajaran siswa. Uji coba produk dilaksanakan melalui tiga tahap yaitu uji coba kelas kecil, uji coba kelas besar dan uji coba lapangan. Analisis data dalam penelitian ini menggunakan analisis deskriptif kualitatif dan analisis deskriptif kuantitatif. Data berupa saran dan masukan dianalisis menggunakan deskriptif kualitatif sedangkan data berupa skor dan nilai dianalisis menggunakan analisis deskriptif kuantitatif.

\section{Validasi Ahli}

Produk bahan ajar menulis teks deskripsi dengan model pembelajaran circuit learning yang sudah dikembangkan diuji kelayakannya oleh validasi ahli materi, ahli grafika dan ahli bahasa. Berdasarkan validasi dari ahli materi, ahli grafika, dan ahli bahasa dinyatakan sudah layak dan digunakan setelah melakukan beberapa revisi berdasarkan saran dan masukan dari para validator ahli. Kelayakan bahan ajar mencapai kriteria layak. Bahan ajar yang telah di revisi dapat digunakan untuk uji coba produk. Perolehan dari validasi ahli dijelaskan pada Tabel 1. Berdasarkan Tabel 1 tersebut bahwa rata-rata kevalidan buku siswa dan guru sebesar 90,33\%. Secara umum bahwa buku siswa dan guru layak digunakan untuk uji coba produk setelah melakukan revisi sesuai catatan pada lembar validasi ahli. 


\section{Uji Coba Kelompok Kelas Kecil}

Uji coba kelompok kelas kecil dilakukan terhadap sepuluh orang siswa kelas VII C SMP Nabiel Husen Samarinda. Uji coba kelompok kelas kecil bertujuan mengetahui kepraktisan bahan ajar menulis deskripsi dengan model pembelajaran circuit learning yang dibuat. Data dikumpulkan menggunakan angket respons guru dan respons siswa. Data hasil uji coba kelompok kelas kecil disajikan pada Tabel 2. Berdasarkan Tabel 2 tersebut diketahui bahwa rata-rata kepraktisan buku guru sebesar 93\% dengan kriteria sangat layak. Sedangkan rata-rata kepraktisan buku siswa sebesar 93\% dengan kriteria sangat layak. Saran dan komentar saat uji coba kelompok kelas kecil dijadikan sebagai dasar revisi bahan ajar menulis deskripsi dengan model pembelajaran circuit learning yang diujikan pada uji coba kelas besar.

\section{Uji Coba Kelompok Kelas Besar}

Uji coba kelompok kelas besar dilakukan terhadap 30 orang siswa kelas VIID SMP Nabil Husen Samarinda. Uji coba kelompok kelas besar bertujuan mengetahui kepraktisan bahan ajar menulis deskripsi dengan model pembelajaran circuit learning yang dibuat. Data dikumpulkan menggunakan angket respons guru dan respons siswa. Data hasil uji coba kelompok kelas besar disajikan pada Tabel 3. Berdasarkan Tabel 3 tersebut diketahui bahwa rata-rata kepraktisan buku guru sebesar 93\% dengan kriteria sangat layak. Sedangkan rata-rata kepraktisan buku siswa sebesar $88 \%$ dengan kriteria sangat layak. Saran dan komentar saat uji coba kelompok kelas kecil dijadikan sebagai dasar revisi bahan ajar menulis deskripsi dengan model pembelajaran circuit learning untuk disebar luaskan.

Tabel 1. Rekapitulasi Validasi Buku dan Media Pembelajaran

\begin{tabular}{cc}
\hline Validator & Persentase \\
\hline Ahli materi & $88 \%$ \\
Ahli bahasa & $97 \%$ \\
Ahli grafika & $86 \%$ \\
Rata-rata & $90,33 \%$ \\
Kategori & Sangat layak \\
\hline
\end{tabular}

Tabel 2. Data Uji Coba Kelompok Kelas Kecil

\begin{tabular}{ccc}
\hline \multirow{2}{*}{ Responden } & \multicolumn{2}{c}{ Persentase } \\
\cline { 2 - 3 } & Buku Siswa & Buku Guru \\
Guru & $93 \%$ & $93 \%$ \\
Siswa & $93 \%$ & $93 \%$ \\
Rata-rata & Sangat layak & Sangat layak \\
Kategori & &
\end{tabular}

Tabel 3. Data Uji Coba Kelompok Kelas Besar

\begin{tabular}{ccc}
\hline \multirow{2}{*}{ Responden } & \multicolumn{2}{c}{ Persentase } \\
\cline { 2 - 3 } & Buku Siswa & Buku Guru \\
Guru & $88 \%$ & $93 \%$ \\
Siswa & $88 \%$ & $93 \%$ \\
Rata-rata & Sangat layak & Sangat layak \\
Kategori & &
\end{tabular}

\section{PENUTUP}


Berdasarkan proses pengembangan hasil validasi dan pembahasan terhadap bahan ajar menulis pengembangan bahan ajar menulis karangan deskripsi dengan menggunakan model circuit learning pada siswa kelas VII Samarinda, maka dapat disimpulkan hasil penelitian sebagai berikut. Pertama, proses pengembangan bahan ajar menulis deskripsi dengan model pembelajaran circuit learning pada siswa kelas VII Samarinda dikembangkan dengan model pengembangan yang mengacu pada rancangan penelitian dan pengembangan modifikasi dari model pengembangan Gall et al. (2003). Model pengembangan yang dilakukan menggunakan 10 tahap dengan perubahan dan modifikasi seperlunya, sesuai kebutuhan peneliti. Bahan ajar yang dikembangkan berupa buku pegangan siswa dengan materi pengembangan bahan ajar menulis karangan deskripsi dengan menggunakan model circuit learning pada siswa kelas VII Samarinda. Produk yang dikembangkan juga telah memenuhi komponen sebagai bahan ajar yang baik untuk digunakan dikarenakan bahan ajar telah sesuai dengan KI-KD, sesuai dengan keadaan siswa, Bahasa yang digunakan mudah, dan juga memiliki kesesuaian warna, ukuran dan jenis huruf menarik yang akan memotivasi siswa agar lebih bersemangat belajar sehingga hasil belajar juga menjadi meningkat.

Kedua, pengembangan bahan ajar menulis deskripsi dengan menggunakan model pembelajaran circuit learning memiliki kualitas produk dengan kriteria " baik" rata-rata persentase $85 \%$ dari hasil validasi dosen ahli materi, dosen ahli grafika, guru pelajaran bahasa Indonesia dan penilaian uji coba produk. Menurut dosen ahli materi kualitas produk "baik" dengan persentase $88,2 \%$. Menurut dosen ahli grafika kualitas produk "baik" dengan persentase $83 \%$. Menurut guru bahasa Indonesia kualitas produk "sangat baik" dengan persentase 97\%. Sedangkan penilaian hasil uji coba kualitas produk "sangat setuju" dengan rata-rata persentase sebesar $84,8 \%$.

Ketiga, pengembangan bahan ajar menulis deskripsi dengan menggunakan model pembelajaran circuit learning pada siswa kelas VII SMP Samarinda memiliki keefektifan sangat baik. Hal ini dapat dilihat dari hasil evaluasi siswa, 81\% siswa dapat mencapai KKM (Kriteria Ketuntasan Minimal) yang ditentukan oleh pihak sekolah.

\section{DAFTAR PUSTAKA}

Gall, M. D., Gall, J. P., \& Borg, W. R. (2003). Educational Research: An Introduction (7th ed.). London: Longman.

Hamalik, O. (2009). Pendidikan Guru Berdasarkan Pendekatan Kompetensi. Jakarta: Bumi Aksara.

Hudiyono, Y., Rokhmansyah, A., \& Elyana, K. (2021). Class Conversation Strategies in Junior High Schools: Study of Conversation Analysis. Cypriot Journal of Educational Sciences, 16(2), 725-738. https://doi.org/10.18844/cjes.v16i2.5649

Rahmawati, A. N. (2018). Identifikasi Masalah yang Dihadapi Guru dalam Penerapan Kurikulum 2013 Revisi di SD. Indonesian Joumal of Primary Education, 2(1), 114-123. https://doi.org/10.17509/ijpe.v2i1.14227

Rajja, Arifin, M. B., \& Mursalim. (2020). Pengembangan Bahan Ajar Menulis Teks Cerpen dengan Metode Cerpen-gram untuk Siswa Kelas IX di Kecamatan Muara Wahau. Diglosia: Jurnal Kajian Bahasa, Sastra, Dan Pengajarannya, 3(1), 24-32. https://doi.org/10.30872/diglosia.v3i1.26

Salahudin, A. (2010). Bimbingan dan Konseling. Bandung: Pustaka Setia. 
Subaidah, S., Susilo, \& Siddik, M. (2020). Pengembangan Bahan Ajar Menulis Cerita Pendek dengan Media Adobe Flash. Diglosia: Jurnal Kajian Bahasa, Sastra, Dan Pengajarannya, 3(4), 423-434. https://doi.org/10.30872/diglosia.v3i4.129

Yundayani, A., Emzir, \& Rafli, Z. (2017). Need analysis: The writing skill instructional material context for academic purposes. English Review: Journal of English Education, 6(1), 59-70. https://doi.org/10.25134/erjee.v6i1.771 